\title{
Specification faced with durability to meet superior level of performance in structural elements buried
}

\section{Especificação frente à durabilidade para atender nível superior de desempenho em elementos estruturais enterrados}
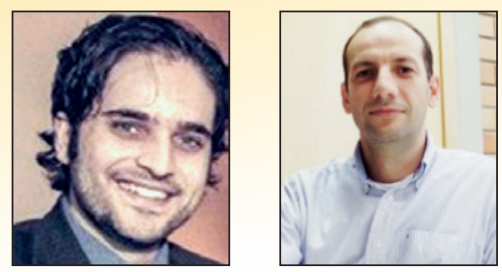

F. BOLINA a fabriciolb@unisinos.br

B.TUTIKIAN a bftutikian@unisinos.br

\begin{abstract}
The performance standard NBR 15575-1: 2013 [1] states that to achieve the higher level of performance for durability, buried concrete structures must achieve a minimum service life (VUP) of 75 years. However, the NBR 6118:2014 [2] does not specify the minimum project properties for the structure fulfill this VUP. The objective of this study is to provide recommendations for structural designers to meet higher performance requirements of NBR 15575:2013 [1] in durability. It was conducted a research of national and international standards and reference publications about the durability and VUP 75 years for structural elements buried. The paper was divided into three parts: $\left(1^{\circ}\right)$ the analysis of the Brazilian and international legal system, as well as reference publications in the area; $\left(2^{\circ}\right)$ discussion of service life prediction models; and $\left(3^{\circ}\right)$ specifications to meet the superior level of durability of structural elements buried.
\end{abstract}

Keywords: performance standard, superior performance, service life, burried structures.

\section{Resumo}

A ABNT NBR 15575-1:2013 [1] estabelece que, para atingir o nível de desempenho superior em termos de durabilidade, as estruturas de concreto armado enterradas devem atender a uma vida útil de projeto (VUP) mínima de 75 anos. Contudo, a norma ABNT NBR 6118:2014 [2] não apresenta recomendações de projeto para que esta VUP seja cumprida. O objetivo deste trabalho é determinar alguns parâmetros projetuais de durabilidade para estas estruturas, visando atender ao requisito de desempenho superior da norma. Para tanto, realizou-se uma pesquisa em normas nacionais e internacionais, além de publicações que remetam a especificações de projeto para vida útil de 75 anos para elementos estruturais enterrados. $\mathrm{O}$ trabalho dividiu-se em três partes: $\left(1^{\circ}\right)$ a análise do sistema normativo (nacional e internacional) e publicações referência da área; $\left(2^{\circ}\right)$ discussão de modelos teóricos de previsão de vida útil; e $\left(3^{\circ}\right)$ definição das especificações de projeto para elementos estruturais enterrados para o nível superior de desempenho.

Palavras-chave: norma de desempenho, desempenho superior, vida útil de projeto, estruturas enterradas.

Unisinos, São Leopoldo, Rio Grande do Sul, Brasil. 


\section{Introduction}

According to the performance standard for residential buildings, ABNT NBR 15575-1:2013[1], a structural system must remain safe, stable and efficient throughout its intended service life. Its constituents must be designed and built so that, under pre-established use conditions, they keep their functional capability throughout its intended service life, which is 75 years for superior performance. ABNT NBR 15575-1:2013[1] provides that the method for assessing the durability of a structure can be to determine whether it complies with the requirements set forth in applicable Brazilian standards or, in the absence thereof, specific international standards addressing the matter.

The purpose of this paper is to provide design recommendations for durability, which may be adopted to size and verify the elements in contact with the ground - such as foundations - in order to achieve the ABNT NBR 15575:2013 [1] superior performance level requirement. In such environments, major aggressive agents are chloride ions, sulfate and humidity.

However, the Brazilian standards for structural design and structural system durability mentioned in ABNT NBR 15575-1:2013 [1] ABNT NBR 6118:2014 [2] and ABNT NBR 12655:2015 [3] do not provide recommendations on how to achieve the durability requirement for buried elements, particularly superior service life. Thus, other references should be sought to meet this purpose, both normative and non-normative.

Therefore, this study was carried out in three stages: (1) analysis of the national and international normative system; (2) review of theoretical models for service life prediction; and (3) definition and proposal of design recommendations for buried structural elements to meet the service life requirement of 75 years. In the first stage, the applicable Brazilian and international standards are presented, as well as relevant technical publications addressing the minimum design requirements to be in compliance with the standard. In the second stage, these normative design parameters are tested through theoretical models. In the third stage, specific design specifications are recommended, integrating that used as reference and the results of the service life prediction models.

\section{Analysis of the brazilian and international normative system}

\subsection{Brazilian standards}

ABNT NBR 15575-1:2013 [1] provides that the design of service life for structural elements of residential buildings must be 50,63 or 75 years to meet the minimum, intermediate and superior durability levels, respectively, as shown in Table 1.

In reinforced concrete structure designs, environmental aggressiveness should be classified according to the criteria used by ABNT NBR 6118:2014 [2], which stipulates that these structures must be designed and built so that, under the environmental conditions established at the time of design, they remain safe, stable and efficient throughout its intended service life. Table 2 shows the criteria for environmental aggressiveness classification proposed by this standard.

\section{Table 1 - Service life for minimum, intermediate and superior levels for residential structures}

\begin{tabular}{|c|c|c|c|c|}
\hline \multirow{2}{*}{ Place } & \multirow{2}{*}{ Examples } & \multicolumn{3}{|c|}{ Service life (years) } \\
\hline & & Minimum & Intermediate & Superior \\
\hline Main structure & $\begin{array}{c}\text { Foundations, structural elements (columns, } \\
\text { beams, slabs and others), structural walls, } \\
\text { peripheral structures, contentions and retaining } \\
\text { walls }\end{array}$ & $\geq 50$ & $\geq 63$ & $\geq 75$ \\
\hline Source: ABNT NBR 1557 & 2013 , edited by the authors & & & \\
\hline
\end{tabular}

Table 2 - Environmental aggressiveness classes

\begin{tabular}{|c|c|c|c|}
\hline $\begin{array}{c}\text { Environmental aggressiveness } \\
\text { classes }\end{array}$ & Aggressiveness & $\begin{array}{l}\text { General classification of } \\
\text { environmental kind for design }\end{array}$ & Risk of structure deterioration \\
\hline I & Weak & $\begin{array}{c}\text { Rural } \\
\text { Submerged }\end{array}$ & Insignificant \\
\hline II & Moderate & Urban & Small \\
\hline III & Strong & $\begin{array}{l}\text { Marine } \\
\text { Industrial }\end{array}$ & Big \\
\hline IV & Very strong & $\begin{array}{l}\text { Industrial } \\
\text { Tidal splash }\end{array}$ & Elevated \\
\hline
\end{tabular}




\section{Table 3 - Correspondence between environmental aggressiveness class and nominal coverings thickness}

\begin{tabular}{|c|c|c|c|c|c|}
\hline \multirow{3}{*}{$\begin{array}{l}\text { Kind of } \\
\text { structure }\end{array}$} & \multirow{3}{*}{ Element } & \multicolumn{4}{|c|}{ Aggressiveness } \\
\hline & & I & II & III & IV \\
\hline & & \multicolumn{4}{|c|}{ Nominal covering thickness $(\mathrm{mm})$} \\
\hline \multirow{3}{*}{ Reinforced concrete } & Slab & 20 & 25 & 35 & 45 \\
\hline & Beam/column & 25 & 30 & 40 & 50 \\
\hline & Buried structural elements & 30 & 30 & 40 & 50 \\
\hline Source: ABNT NBR 611 18:2014 & & & & & \\
\hline
\end{tabular}

\section{Table 4 - Correspondence between environmental aggressiveness class and concrete quality, for reinforced concrete structures}

\begin{tabular}{|c|c|c|c|c|}
\hline \multirow{2}{*}{ Concrete } & \multicolumn{4}{|c|}{ Environmental aggressiveness class } \\
\hline & I & II & III & IV \\
\hline Water/cement ratio, in mass & $\leq 0,65$ & $\leq 0,60$ & $\leq 0,55$ & $\leq 0,45$ \\
\hline Concrete class (ABNT NBR 8953) & $\geq \mathrm{C} 20$ & $\geq \mathrm{C} 25$ & $\geq \mathrm{C} 30$ & $\geq \mathrm{C} 40$ \\
\hline Cement consumption for concrete cubic meter, $\mathrm{kg} / \mathrm{m}^{3}$ & $\geq 260$ & $\geq 280$ & $\geq 320$ & $\geq 360$ \\
\hline Source: ABNT NBR 12655:2015 & & & & \\
\hline
\end{tabular}

\section{Table 5 - Requirements for exposed concrete of sulfates solutions}

\begin{tabular}{|c|c|c|c|c|}
\hline $\begin{array}{l}\text { Exposure conditions } \\
\text { in function of } \\
\text { aggressiveness }\end{array}$ & $\begin{array}{l}\text { Water soluble sulfate } \\
\left(\mathrm{SO}_{4}\right) \text { in soil - \%, } \\
\text { in mass }\end{array}$ & $\begin{array}{l}\text { Soluble sulfate }\left(\mathrm{SO}_{4}\right) \\
\text { in water - ppm }\end{array}$ & $\begin{array}{l}\text { Maximum w/c ratio, in } \\
\text { mass, for regular } \\
\text { aggregate concrete* }\end{array}$ & $\begin{array}{l}\text { Minimum } \mathrm{f}_{\mathrm{ck}} \\
\text { (for regular ou } \\
\text { light aggregate } \\
\text { concrete) - MPa }\end{array}$ \\
\hline Weak & 0,00 a 0,10 & 0 a 150 & - & - \\
\hline Moderate ${ }^{\star *}$ & 0,10 a 0,20 & 150 a 1500 & 0,50 & 35 \\
\hline Severe ${ }^{\star * *}$ & Above de 0,20 & Above de 1500 & 0,40 & 40 \\
\hline \multicolumn{5}{|c|}{$\begin{array}{l}\text { * Low w/c ratio or high strength could be necessary to obtain low concrete permeability or steel corrosion protection or freezing and thawing; }{ }^{* *} \text { See water; }{ }^{* \star *} \text { For seve } \\
\text { aggressiveness is necessary to use sulfate resistant cements. }\end{array}$} \\
\hline Source: ABNT NBR 12655:2015 & & & & \\
\hline
\end{tabular}

Depending on the environmental classification, ABNT NBR 6118:2014 [2] presents recommendations regarding reinforcement cover thickness. This cover thickness is intended to ensure physical, chemical and mechanical protection of the reinforcement, as shown in Table 3.

According ABNT NBR 12655:2015[3], when the requirements provided in ABNT NBR 6118:2014 [2] are met, structural durability will depend on the characteristics of the concrete constituents. Therefore, this standard defines the maximum water/cement ratio, minimum compressive strength, and minimum cement consumption, as shown in Table 4. It also shows the ground aggressiveness classification depending on the amount of water-soluble sulfate $\left(\mathrm{SO}_{4}\right)$ in soil, as shown in Table 5.

The recommendations provided by these standards are assumed to be for a service life of 50 years. ABNT NBR 8681:2004 [4] determines that for actions that vary over time (variable actions) a reference period is required for them to be equaled or overcome. These values were defined by consensus, having a $25 \%-35 \%$ probability that they will be exceeded during 50 years.

\subsection{International standards and reference literature}

According to Tutikian, Isaía e Helene (2011) [5], the durability of concrete structures depends on both extrinsic factors (presence of salts, sea spray, acid rain) and intrinsic factors (cement type, water/cement ratio, additives additions, etc.). This paper focused on the assessment of intrinsic factors required to have a service life of 75 years. The intrinsic factors recommended by the national and 


\section{Table 6 - Recommendations for high severe aggressiveness zones}

\begin{tabular}{|c|c|c|c|c|c|c|}
\hline \multirow{3}{*}{$\begin{array}{l}\text { Aggressive } \\
\text { ness zone }\end{array}$} & \multicolumn{3}{|c|}{ Sulfate concentration in $\mathrm{SO}_{3}$} & \multirow{3}{*}{$\begin{array}{l}\text { Cement } \\
\text { type }\end{array}$} & \multirow{3}{*}{$\begin{array}{l}\text { Minimum } \\
\text { cement } \\
\text { consumption } \\
\left(\mathrm{kg} / \mathrm{m}^{3}\right)\end{array}$} & \multirow{3}{*}{$\begin{array}{l}\text { Maximum } \\
\text { w/c ratio }\end{array}$} \\
\hline & \multicolumn{2}{|c|}{ Environmental } & \multirow{2}{*}{$\begin{array}{l}\text { Ground } \\
\text { water }\end{array}$} & & & \\
\hline & Total $\mathrm{SO}_{3}$ & $\begin{array}{c}\text { SO, in 2:1 ratio of } \\
\text { water and soil }\end{array}$ & & & & \\
\hline 4 & 1 a 2 & 3 a 5 & 2,5 a 5 & $\begin{array}{l}\text { Supersulfated } \\
\text { cement or Portland } \\
\text { cement resistant } \\
\text { to sulfates }\end{array}$ & 370 & 0,45 \\
\hline
\end{tabular}

international normative system for durability are (a) minimum cement consumption; (b) minimum reinforcement cover thickness; and (c) maximum water/cement ratio. Concrete compressive strength is also mentioned but, as it is related to water/cement ratio, it does not require further specification. The type of cement used could also affect the durability of these structures by chemical deterioration, but it is rarely described in the standards.

\subsubsection{Minimum cement consumption}

Cement consumption is often related to parameters such as mechanical strength, durability, fluidity, setting time, and others. Ac- cording to BRE (2005) [6], penetration of sulfate ions occurs in porous alkaline solutions resulting from cement hydration, leading to damage such as expansion and cracking. By using sulfate-resistant cement, the level of tricalcium aluminate is kept at a minimum, thus reducing the impact of such reaction on the structure.

Regarding structures embedded in sulfate environments, the recommendations provided in IS 456:2000 [7] should be noted. This regulation has a qualitative classification by zone of potentially aggressive environments to concrete structures. The Indian standard mentions buried structures, classifying them under aggressiveness zone number 4 . For structures in these circumstances, the standard determines that minimum cement consumption should be $370 \mathrm{~kg} / \mathrm{m}^{3}$, as shown in Table 6 .

\section{Table 7 - Specifications to attend service life of 100 years in buried reinforced or pretensed concrete elements}

\begin{tabular}{|c|c|c|c|c|c|c|c|c|c|c|}
\hline \multirow{2}{*}{$\begin{array}{c}\text { Corrosion } \\
\text { type }\end{array}$} & \multirow{2}{*}{$\begin{array}{l}\text { Exposition } \\
\text { condition }\end{array}$} & \multirow{2}{*}{$\begin{array}{l}\text { Cement } \\
\text { type }\end{array}$} & \multicolumn{8}{|c|}{ Nominal covering thickness of concrete $(\mathrm{mm})$} \\
\hline & & & 40 & 45 & 50 & 55 & 60 & 65 & 70 & 75 \\
\hline \multirow{10}{*}{$\begin{array}{c}\text { Chloride } \\
\text { (except } \\
\text { see } \\
\text { water) }\end{array}$} & \multirow{4}{*}{$\begin{array}{c}\text { Salt } \\
\text { spray, but } \\
\text { without } \\
\text { direct } \\
\text { contact }\end{array}$} & $\begin{array}{l}\text { I, IIA, IIB-S, } \\
\text { SRPC }\end{array}$ & $\begin{array}{c}C 45 / 55 \\
0,40 ; 380\end{array}$ & $\begin{array}{c}C 40 / 50 \\
0,45 ; 360\end{array}$ & $\begin{array}{c}\text { C35/45 } \\
0,50 ; 340\end{array}$ & $\begin{array}{l}\text { C32/40, } \\
0,55 ; 320\end{array}$ & $\begin{array}{c}C 28 / 35 \\
0,60 ; 300\end{array}$ & $\begin{array}{c}C 28 / 35 \\
0,60 ; 300\end{array}$ & $\begin{array}{c}C 28 / 35 \\
0,60 ; 300\end{array}$ & $\begin{array}{c}C 28 / 35 \\
0,60 ; 300\end{array}$ \\
\hline & & $\|B-V\| A$, & - & - & $\begin{array}{c}C 35 / 45 \\
0,45 ; 360\end{array}$ & $\begin{array}{l}\text { C32/40, } \\
0,50 ; 340\end{array}$ & $\begin{array}{c}C 28 / 35 \\
0,55 ; 320\end{array}$ & $\begin{array}{c}C 28 / 35 \\
0,55 ; 320\end{array}$ & $\begin{array}{c}C 28 / 35 \\
0,55 ; 320\end{array}$ & $\begin{array}{c}C 28 / 35 \\
0,55 ; 320\end{array}$ \\
\hline & & IIIB & - & - & $\begin{array}{l}\text { C32/40, } \\
0,45 ; 360\end{array}$ & $\begin{array}{c}C 28 / 35 \\
0,50 ; 340\end{array}$ & $\begin{array}{c}C 28 / 35 \\
0,55 ; 320\end{array}$ & $\begin{array}{c}C 28 / 35 \\
0,55 ; 320\end{array}$ & $\begin{array}{c}C 28 / 35 \\
0,55 ; 320\end{array}$ & $\begin{array}{c}C 28 / 35 \\
0,55 ; 320\end{array}$ \\
\hline & & IVB-V & - & - & $\begin{array}{c}C 28 / 35 \\
0,45 ; 360\end{array}$ & $\begin{array}{c}C 25 / 30 \\
0,50 ; 340\end{array}$ & $\begin{array}{c}C 20 / 30 \\
0,55 ; 320\end{array}$ & $\begin{array}{c}C 20 / 30 \\
0,55 ; 320\end{array}$ & $\begin{array}{c}C 20 / 30 \\
0,55 ; 320\end{array}$ & $\begin{array}{c}C 20 / 30 \\
0,55 ; 320\end{array}$ \\
\hline & \multirow{3}{*}{$\begin{array}{l}\text { Wet, } \\
\text { rarely } \\
\text { dry }\end{array}$} & $\begin{array}{l}\text { I, IIA, IIB-S, } \\
\text { SRPC }\end{array}$ & - & - & - & - & - & $\begin{array}{c}C 45 / 55 \\
0,40 ; 380\end{array}$ & $\begin{array}{c}C 40 / 50 \\
0,40 ; 380\end{array}$ & $\begin{array}{c}C 35 / 45 \\
0,45 ; 360\end{array}$ \\
\hline & & $\|B-V\| A A$, & - & - & - & $\begin{array}{c}C 40 / 50 \\
0,35 ; 380\end{array}$ & $\begin{array}{c}C 35 / 45 \\
0,40 ; 380\end{array}$ & $\begin{array}{l}\text { C32/40, } \\
0,45 ; 360\end{array}$ & $\begin{array}{c}C 28 / 35 \\
0,50 ; 340\end{array}$ & $\begin{array}{c}C 25 / 30 \\
0,55 ; 320\end{array}$ \\
\hline & & IIB, IVB-V & - & - & - & $\begin{array}{l}\text { C32/40, } \\
0,40 ; 380\end{array}$ & $\begin{array}{c}C 28 / 35 \\
0,45 ; 360\end{array}$ & $\begin{array}{c}C 25 / 30 \\
0,50 ; 340\end{array}$ & $\begin{array}{c}C 25 / 30 \\
0,55 ; 320\end{array}$ & $\begin{array}{c}C 25 / 30 \\
0,55 ; 320\end{array}$ \\
\hline & \multirow{3}{*}{$\begin{array}{l}\text { Wetting } \\
\text { and } \\
\text { drying } \\
\text { cycles }\end{array}$} & $\begin{array}{l}\text { I, IIA, IIB-S, } \\
\text { SRPC }\end{array}$ & - & - & - & - & - & $\begin{array}{c}C 45 / 55 \\
0,35 ; 380\end{array}$ & $\begin{array}{c}C 40 / 50 \\
0,40 ; 380\end{array}$ & $\begin{array}{c}C 35 / 45 \\
0,45 ; 360\end{array}$ \\
\hline & & $\|B-V\| A A$, & - & - & - & $\begin{array}{c}C 40 / 50 \\
0,35 ; 380\end{array}$ & $\begin{array}{c}C 35 / 45 \\
0,40 ; 380\end{array}$ & $\begin{array}{l}\text { C32/40, } \\
0,45 ; 360\end{array}$ & $\begin{array}{c}C 28 / 35 \\
0,50 ; 340\end{array}$ & $\begin{array}{c}C 25 / 30 \\
0,55 ; 320\end{array}$ \\
\hline & & IIIB, IVB-V & - & - & - & $\begin{array}{l}\text { C32/40, } \\
0,40 ; 380\end{array}$ & $\begin{array}{c}C 28 / 35 \\
0,45 ; 360\end{array}$ & $\begin{array}{c}C 25 / 30 \\
0,50 ; 340\end{array}$ & $\begin{array}{c}C 25 / 30 \\
0,50 ; 340\end{array}$ & $\begin{array}{c}C 25 / 30 \\
0,50 ; 340\end{array}$ \\
\hline
\end{tabular}


BS EN 206-1:2006 [8] recommendations for cement consumption are similar to those provided by IS 456:2000 [7]. Similarly to Brazilian regulations, these standards do not have a description about the service life used. For both ACI 318-11:2002 [9] and ABNT NBR 6118:2014 [2], service life is assumed to be 50 years, based on the time of return of the design variable actions. These recommendations are more conservative than those adopted by ABNT NBR 6118:2014 [2] for buried structural elements.

\subsubsection{Nominal cover to reinforcement}

Concrete cover is used to provide the reinforcement with chemical and physical protection in order to ensure that the superior performance level is obtained, that is, a minimum service life of 75 years. Table 3, taken from ABNT NBR 6118:2014 [2], specifies the minimum reinforcement covers for a service life of 50 years; for more strict criteria, additional information is required.

According to Neville \& Brooks [10], it is possible for structures to have a service life of 100 years if specific nominal covers are adopted based on the type and exposure condition of structures, in addition to the concrete strength classification. This is the principle adopted in ABNT NBR 6118:2014 [2] and ABNT NBR 12655:2015 [3] Within this context, Table 7 shows the BS 8500-1:2006 [11] specifications for a service life of 100 years, focusing on chloride ion attack. Thus, for wet and rarely dry conditions in environments potentially prone to corrosion by chloride, reinforcement covers should

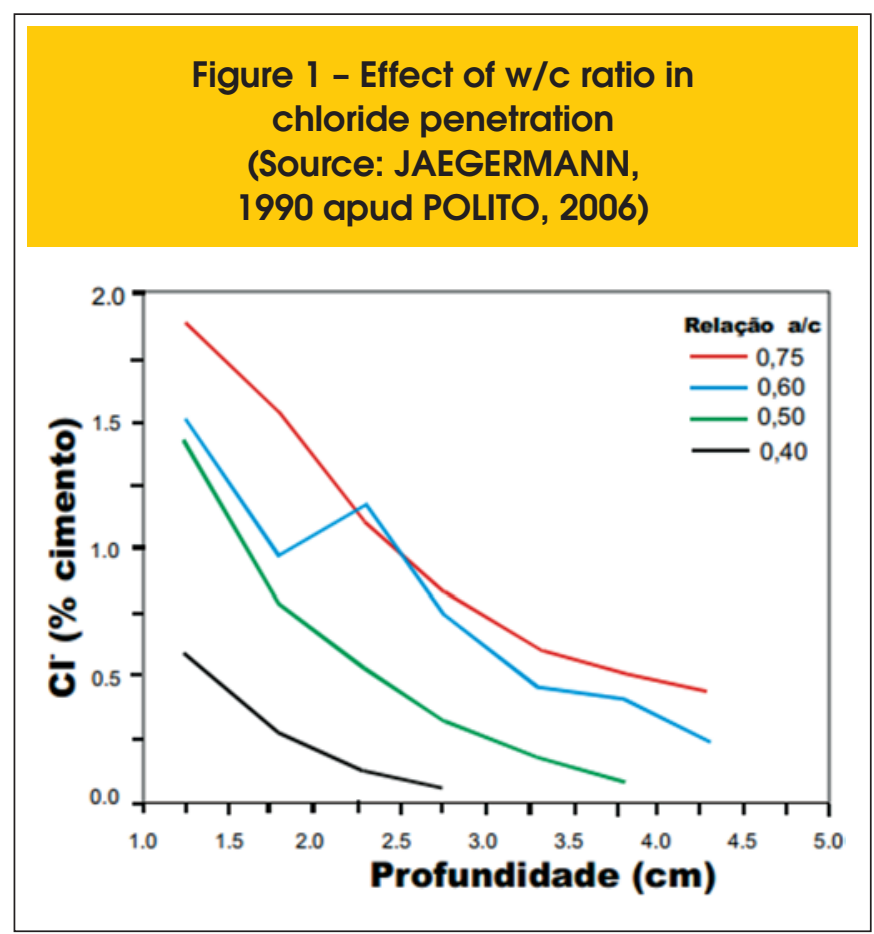

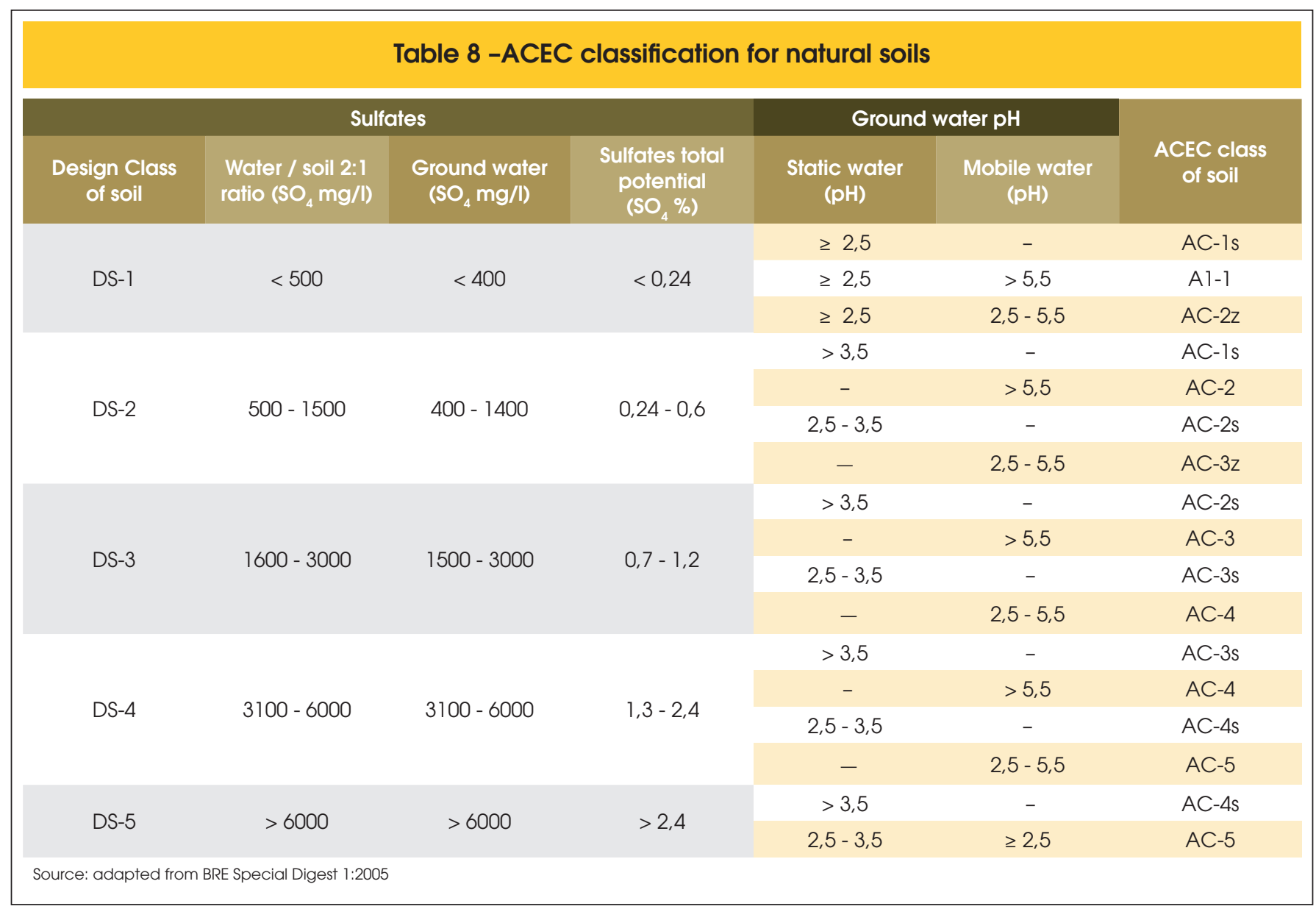




\begin{tabular}{|c|c|c|}
\hline \multicolumn{3}{|c|}{$\begin{array}{c}\text { Table } 9 \text { - DC class and APM number for } \\
\text { concrete elements in zones with hydraulic } \\
\text { gradient less than or equal to 5: concrete for } \\
\text { general use in situ }\end{array}$} \\
\hline \multirow{2}{*}{$\begin{array}{c}\text { ACEC class } \\
\text { of soil }\end{array}$} & \multicolumn{2}{|c|}{ Planned service life } \\
\hline & Until 50 years & Until 100 years \\
\hline AC-1s, AC-1 & DC-1 & DC-1 \\
\hline$A C-2 s, A C-2$ & DC-2 & DC-2 \\
\hline$A C-2 z$ & $D C-2 z$ & $D C-2 z$ \\
\hline$A C-3 s$ & DC-2 & DC-3 \\
\hline$A C-3 z$ & DC-3z & DC-3z \\
\hline AC-3 & DC-2 & DC-3 \\
\hline$A C-4 s$ & DC-3 & DC-3 \\
\hline$A C-4 z$ & $D C-4 z$ & $D C-4 z$ \\
\hline AC-4 & DC-3 & DC-4 \\
\hline$A C-4 m s$ & DC- $-4 m$ & DC- $4 m$ \\
\hline$A C-4 m$ & DC-4m & DC-4m \\
\hline$A C-5 z$ & $\mathrm{DC}-4 \mathrm{z}+\mathrm{APM} 3 \mathrm{a}$ & $D C-4 z+A P M 3 a$ \\
\hline$A C-5$ & $\mathrm{DC}-4+\mathrm{APM} 3{ }^{\mathrm{a}}$ & $\mathrm{DC}-4+\mathrm{APM} 3^{\mathrm{a}}$ \\
\hline$A C-5 m$ & $A C-4 m+A P M 3 a$ & $A C-4 m+A P M 3 a$ \\
\hline \multicolumn{3}{|c|}{ Source: adapted from BRE Special Digest 1:2005 } \\
\hline
\end{tabular}

be at least $55 \mathrm{~mm}$, with $\mathrm{f}_{\mathrm{ck}}$ of $40 \mathrm{MPa}$, maximum water/cement ration of 0.40 , and minimum cement consumption of $380 \mathrm{~kg} / \mathrm{m}^{3}$. BS 8500-1:2006 [11] uses concrete cover, compressive strength, water/cement ratio and cement consumption to ensure structural durability, similarly to ABNT NBR 6118:2014 [2], ABNT NBR 12655:2015 [3] and other international standards.

\subsubsection{Water/cement ratio}

As the thickness of reinforcement covers, maximum water/cement ratio will also depend on environmental aggressiveness. In order to determine the ratio for a service life of 75 years for buried structures, attack by chloride and sulfate should be considered, as well as soil humidity.

According to CCAA (2009) [12] and Figueiredo (2011) [13], concrete resistance against chloride attack depends on the material porosity, particularly size, distribution and interconnectivity of paste pores. This variable is directly proportional to the water/cement ratio. Figure 1 shows the effect of such variable on chloride ion penetration (POLITO, 2006 [14]). Table 8 shows the BS 8500-1:2006[11] specification for maximum water/cement ratio allowed in designs for areas having this type of environmental aggressiveness.

ACI 318-11:2002 [9], similarly to Brazilian standards, does not discriminate the intended service life by adopting design parameters (it is assumed to be 50 years), according to ASCE 7-05 (2005) [15]. However, similarly to the Brazilian standard, ACl 318-11:2002[9] adopts an environmental classification based on aggressiveness. Considering a structure exposed to humidity and external chloride sources (class 2), a maximum water/cement ration of 0.4 is recommended, consistent with the BS 8500-1:2006 [11] recommendation. Another hypothesis to be considered when analyzing the durability of buried structures is attack by sulfates in the ground, particularly in industrial areas. Mehta \& Monteiro (2014) [16] note that magnesium sulfate, sodium and potassium are commonly found in groundwater.

According to Isaia (2011) [17], sulfate attack occurs by chemical reaction of the sulfate ion with the aluminate components of hard-

\section{Table 10 - Concrete quality for resistance to chemical attack: concrete for general use in situ}

\begin{tabular}{|c|c|c|c|c|c|c|}
\hline \multirow{2}{*}{$\begin{array}{l}\text { DC } \\
\text { class }\end{array}$} & \multirow{2}{*}{$\begin{array}{c}\text { w/c } \\
\text { maximum }\end{array}$} & \multicolumn{4}{|c|}{ Minimum cement consumption $\left(\mathrm{kg} / \mathrm{m}^{3}\right)$, for maximum aggregate size } & \multirow{2}{*}{$\begin{array}{l}\text { ACEC class } \\
\text { of soil }\end{array}$} \\
\hline & & $\geq 40 \mathrm{~mm}$ & $20 \mathrm{~mm}$ & $14 \mathrm{~mm}$ & $10 \mathrm{~mm}$ & \\
\hline \multirow{3}{*}{ DC-4 } & 0,45 & 340 & 360 & 380 & 380 & $\mathrm{~F}$ \\
\hline & 0,4 & 360 & 380 & 380 & 380 & E \\
\hline & 0,35 & 380 & 380 & 380 & 380 & $D, G$ \\
\hline Group & \multicolumn{4}{|c|}{ Cements } & \multicolumn{2}{|c|}{ Combinations } \\
\hline A & \multicolumn{4}{|c|}{$\begin{array}{c}\text { CEM I, CEM ॥/A-D, CEM ॥/A-Q, CEM ॥/A-S, CEM ॥/B-S, CEM ॥/A-V, CEM } \\
\text { ॥/B-V, CEM ॥/A, CEM II/B }\end{array}$} & \multicolumn{2}{|c|}{$\begin{array}{l}\text { CIIA-V, C\|B-V, CII-S, CIIIA, C\|IB, } \\
\text { C\|A-D, C\|A-Q }\end{array}$} \\
\hline B & \multicolumn{4}{|c|}{ CEM II/A-L, CEM I/A-LL } & \multicolumn{2}{|c|}{$C\|A-L, C\| A-L L$} \\
\hline C & \multicolumn{4}{|c|}{ CEM ॥/A-L, CEM II/A-LL } & \multicolumn{2}{|c|}{ C\|A-L, C\|A-LL } \\
\hline D & \multicolumn{4}{|c|}{ CEM $\| / B-V+S R, C E M ~ I I / A+S R$} & \multicolumn{2}{|c|}{$C\|B-V+S R, C\| I A+S R$} \\
\hline E & \multicolumn{4}{|c|}{ CEM IV/B (V), VLH IV/B (V) } & \multicolumn{2}{|c|}{ CIVB-V } \\
\hline $\mathrm{F}$ & \multicolumn{4}{|c|}{ CEM III/B+SR } & \multicolumn{2}{|c|}{$\mathrm{C} \| \mathrm{B}+\mathrm{SR}$} \\
\hline$G$ & \multicolumn{4}{|c|}{ SRPC } & \multicolumn{2}{|c|}{-} \\
\hline
\end{tabular}


ened concrete. Mehta \& Monteiro (2014) [16] argue that concrete degradation can occur as expansion and cracking. Concrete expansion can cause cracking, which increases concrete permeability, facilitating the penetration of other aggressive agents in the structural element.

BRE (2005) [6] proposes a methodology to select sulfate-resistant concrete. The starting point is to determine the ACEC (Aggressive Chemical Environment for Concrete) class of the ground, as shown in Table 9. This classification depends on the total potential for sulfate and on the $\mathrm{pH}$ of the groundwater. After that it is possible to determine the DC (Design Chemical) class of concrete for a service life of 100 years (Table 10Erro! A origem da referência não foi encontrada.). With this it is possible to determine the maximum water/cement ratio, cement type and consumption (Table 9).

For comparison purposes with the water/cement ratio recommendations for chloride attack, the ground aggressiveness classification is considered to be AC-5, the most severe level condition of exposure to sulfates. In this class, for a service life of 100 years the concrete class is DC-4. Accordingly, a water/cement ratio of $0.35,0.4$ or 0.45 is recommended (values associated with other concrete characteristics).

\subsubsection{Cement type}

ABNT NBR 5736:1999 [18] allows adding up to $50 \%$ of pozzolan to clinker, calcium sulfate and carbonate material to produce CPIV. Pozzolanic cement, due to the reaction of the pozzolan with the calcium hydroxide produced by cement hydration, has increased durability, because the calcium hydroxide, which is highly soluble and leachable, is combined as hydrated calcium silicate, more resistant to aggressive agents. The same occurs with CPIII, which, according to ABNT NBR 5735:1991 [19], is a mixture of clinker, calcium sulfate and carbonate material with $30 \%-70 \%$ of blastfurnace slag.

These types o cement are therefore recommended for applications exposed to flowing water and aggressive environments. They are less permeable, more durable, having higher long-age compressive strength as compared to concrete produced from Portland ce- ment with lower levels of additions. They have lower heat of hydration during the setting period because their reactions are slower, being recommended for high volume applications such as foundation blocks, for example.

Also, the alkali-aggregate reaction, which can cause expansion of the finished structure, is mitigated by adding pozzolan, according to ABNT NBR 15577:2008 [20]. Nagesh (2012) [21] states that application of this type of cement is recommended for the production of structural elements potentially prone to this kind of attack, such as those in contact with the ground.

ABNT NBR 6118:2014 [2] defines carbon dioxide and chloride ions as the main aggressive agents for concrete structures, and they should be anticipated and prevented in the design and use stage of the building. This standard also refers to attack by leaching processes and expansion reactions, such as that caused by alkali-aggregate and sulfates. In the absence of experimental test values, Medeiros, Andrade e Helene (2011) [22] recommend adopting a guiding specification, as shown in Table 11 and Table 12, using pozzolanic additives.

Therefore, in order to analyze the durability of buried structures in terms of design, the chemical composition (type) and minimum cement consumption should be assessed, among other factors.

\subsection{Service life prediction models}

Theoretical models for service life prediction are useful to understand the propagation rate of aggressive agents in concrete and to determine the required reinforcement cover and other means of protection, such as reduced water/cement ratio, argue Bolina e Tutikian [23]. Interpreting these theoretical models, which are usually developed from experimental tests, helps to understand the rate of chemical deterioration of concrete constituents.

To determine the durability of concrete structures, service life prediction models must be analyzed for chloride ion penetration, which will basically depend on the material porosity and reinforcement cover, in the worst scenario, as penetration is rather quick. The most adequate theoretical models are by Helene (1993) [24] and Bob (1996) [25].

\begin{tabular}{|c|c|c|c|c|}
\hline \multirow{2}{*}{$\begin{array}{l}\text { Concrete } \\
\text { class }\end{array}$} & \multirow{2}{*}{$\begin{array}{l}\text { Strength } \\
\text { class }\end{array}$} & \multirow{2}{*}{$\begin{array}{l}\text { Maximum } \\
\text { w/c ratio }\end{array}$} & Deterioration of carbonation & Deterioration of chlorides \\
\hline & & & Addition content & Addition content \\
\hline Durable & $\geq \mathrm{C} 50$ & $\leq 0,38$ & $\begin{array}{l}\leq 10 \% \text { of pozzolan, metakaolin or blast } \\
\text { furnace slag }\end{array}$ & $\begin{array}{c}\leq 20 \% \text { of pozzolan or metakaolin } \\
\leq 65 \% \text { of blast furnace slag, galvanized } \\
\text { steel or stainless steel }\end{array}$ \\
\hline Resistant & $\begin{array}{l}\text { C35 } \\
\text { C40 } \\
\text { C45 }\end{array}$ & $\leq 0,50$ & $\begin{array}{l}\leq 10 \% \text { of pozzolan or metakaolin } \\
\leq 15 \% \text { of blast furnace slag }\end{array}$ & $\begin{array}{c}\leq 10 \% \text { of pozzolan or metakaolin } \\
\leq 35 \% \text { of blast furnace slag, galvanized } \\
\text { steel or stainless steel }\end{array}$ \\
\hline Normal & $\begin{array}{l}\text { C25 } \\
\text { C30 }\end{array}$ & $\leq 0,62$ & Any & Any \\
\hline Ephemeron & $\begin{array}{l}\mathrm{C} 10 \\
\mathrm{C} 15 \\
\mathrm{C} 20\end{array}$ & Any & Any & Any \\
\hline
\end{tabular}




\subsubsection{Helene (1993) [24]}

This model determines the penetration depth of chloride ion according to equation 1 .

$$
\mathrm{y}_{\mathrm{c}}=\mathbf{k} \cdot \sqrt{\mathrm{t}}
$$

Where $\mathrm{t}$ is time, in years, and $\mathrm{k}$ is the chloride ion diffusion coefficient Helene (1993) [24] suggests that chloride concentration in a structural element should be expressed in relation to the cement mass $\left(\mathrm{Cl}_{\text {cimento }}\right.$ ), directly influenced by the chloride concentration in the environment $\left(\mathrm{Cl}_{\mathrm{amb}}\right)$. This correlation is expressed in equation 2 .

$$
\mathrm{Cl}_{\text {cimenta }}=\frac{\mathrm{Cl}_{\text {amb }} \cdot \mathrm{Ab} \cdot \gamma \cdot 0,01}{\mathrm{C}}
$$

Where $\mathrm{Cl}_{\text {cimento }}$ is cement consumption, in $\mathrm{kg} / \mathrm{m}^{3}, \mathrm{Ab}$ is maximum water absorption in concrete, expressed in $\%$, and $\gamma$ is the bulk density of concrete, in $\mathrm{kg} / \mathrm{m}^{3}$.

\subsubsection{Bob (1996) [25]}

After verifications based on long-term experiments data, Bob (1996) [26] observed that the modeling of chloride penetration could be expressed by equation 3 .

$$
\mathrm{x}_{\mathrm{nt}}=150 \cdot\left(\frac{\mathrm{c} \cdot \mathrm{kl} \cdot \mathrm{k} 2 \cdot \mathrm{d}}{\mathrm{fc}}\right) \cdot \sqrt{\mathrm{t}}
$$

Where $x_{m}$ is the average chloride penetration depth, in millimeters, $\mathrm{fc}$ is the characteristic compressive strength of concrete, in MPa, c is the fixing ability of chlorines, $\mathrm{k} 1$ is the influence of temperature on the model, $k 2$ is the influence of humidity and $d$ is the ratio between critical concentration and surface concentration of chlorides in the structure.

\section{Results and discussion}

Based on international standards and reference publications in the area, minimum parameters were proposed to ensure a service life of 75 years for buried structures, reaching the superior level of the Performance Standard. These parameters build on standard recommendations that provide specifications for this kind of structures, such as ACI 318-1:2002 [9], EN 206-1:2000 [8], IS 456:2000 [7], ABNT NBR 15577-1 [26] and BS 8500-1:2006 [11]. These durability parameters, similarly to ABNT NBR 6118:2014[2], are minimum compressive strength, maximum water/cement ratio, minimum cement consumption, cement type and nominal reinforcement cover. From these prediction models design parameters were derived to yield a service life of 75 years for buried structures in slightly aggressive, moderately aggressive and highly aggressive environments, as shown in Table 13. The models of Helene (1993) [24] and Bob (1996) [25] were assessed to find an average value. As these models represent chloride ion attack, a critical value was obtained for buried elements.

Table 14 shows the design properties to meet such requirement, where all parameters are numerically supported by and in line with national and international references.

Specifications for water/cement ratio followed BS 8500-1:2006 [11]. This standard also provides for variations of water/cement ratio and cover, which was not adopted in this paper.

It was used the aggressiveness classification of Brazilian stan-

\begin{tabular}{|c|c|c|c|c|}
\hline \multicolumn{5}{|c|}{$\begin{array}{l}\text { Table } 12 \text { - Classification of concrete strength against the risk of deterioration } \\
\text { by leaching or by formation of expansive compounds }\end{array}$} \\
\hline \multirow[b]{2}{*}{$\begin{array}{l}\text { Durable } \\
\text { resistant }\end{array}$} & \multirow[b]{2}{*}{$\begin{array}{l}\text { Strength } \\
\text { class }\end{array}$} & \multicolumn{2}{|r|}{ Deterioration of expansion } & Deterioration of leaching \\
\hline & & $\begin{array}{c}\mathrm{C}_{3} \mathrm{~A} \\
\text { content in } \\
\text { anhydrous } \\
\text { cement }\end{array}$ & Addition content & Addition content \\
\hline Normal & $\geq$ C50 & $\leq 5 \%$ & $\begin{array}{c}\geq 20 \% \text { of pozzolan or metakaolin } \geq 65 \% \text { of } \\
\text { blast furnace slag }\end{array}$ & $\begin{array}{l}\geq 20 \% \text { of pozzolan or metakaolin } \\
\geq 65 \% \text { of blast furnace slag }\end{array}$ \\
\hline Ephemeron & $\begin{array}{l}\text { C35 } \\
\text { C40 } \\
\text { C45 }\end{array}$ & $\leq 5 \%$ & $\begin{array}{l}\geq 10 \% \text { de pozolana ou metacaulim } \\
\quad \geq 35 \% \text { of blast furnace slag }\end{array}$ & $\begin{array}{l}\geq 10 \% \text { of pozzolan or metakaolin } \\
\quad \geq 35 \% \text { of blast furnace slag }\end{array}$ \\
\hline Durable & $\begin{array}{l}\mathrm{C} 25 \\
\mathrm{C} 30\end{array}$ & $\leq 8 \%$ & Any & Any \\
\hline Resistant & $\begin{array}{l}\mathrm{C} 10 \\
\mathrm{C} 15 \\
\mathrm{C} 20\end{array}$ & Any & Any & Any \\
\hline
\end{tabular}
dards, such as ABNT NBR 12655:2015 [3], and international standards, such as ACl 318-11:2002 [9], EN 206-1:2000 [8] e IS 
456:2000 [7], where environments are categorized as slightly aggressive, moderately aggressive and severely aggressive. It should be noted that for a slightly aggressive class a nominal cover of 45 $\mathrm{mm}$ is required, which, according to service life prediction models, will protect the structure for 75 years. If the structure is located in a moderately aggressive environment, nominal cover should be 55 $\mathrm{mm}$. And for severely aggressive environments the specification if for nominal cover of $70 \mathrm{~mm}$. Use of fibers or cover reinforcement is recommended when cover exceeds $50 \mathrm{~mm}$ (IS 456:2000 [7]).

\section{Conclusions}

ABNT NBR 15575-2:2013 [1] provides unprecedented durability parameters, not yet seen in Brazil. As it is a performance standard,

Table 13 - Service life prediction model for elements subjected to severe aggression by chlorides, according (a) Helene (1993) (24) e (b) Bob (1996) (25)

\begin{tabular}{|c|c|c|c|c|c|}
\hline & & & & \multicolumn{2}{|c|}{ Weak aggressiv } \\
\hline \multicolumn{6}{|c|}{ (a) } \\
\hline \multirow{6}{*}{$\begin{array}{r}\gamma \\
\text { Cenvironmental } \\
\text { Abh }\end{array}$} & 340 & $\mathrm{~kg} / \mathrm{m}^{3}$ & Clsup. & 0,0441 & $\%$ \\
\hline & 2500 & & k & 0,0441 & \\
\hline & 0,3 & & $\dagger$ & 75 & years \\
\hline & 2 & $\%$ & y & 3,309 & $\mathrm{~cm}$ \\
\hline & Cover & & 33,1 & & \\
\hline & $c+\Delta C$ & & 43,1 & $\mathrm{~mm}$ & \\
\hline
\end{tabular}

INPUT DATA (gray)

(b)

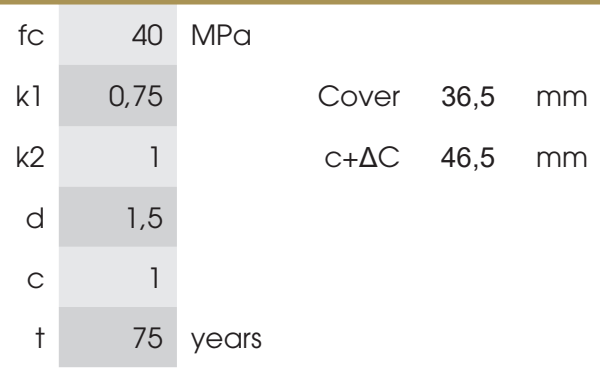

\begin{tabular}{|c|c|c|c|c|c|}
\hline \multicolumn{6}{|c|}{ INPUT DATA (gray) } \\
\hline & & & & \multicolumn{2}{|c|}{ Moderate aggress } \\
\hline \multicolumn{6}{|c|}{ (a) } \\
\hline C & 370 & $\mathrm{~kg} / \mathrm{m}^{3}$ & Clsup. & 0,059028 & $\%$ \\
\hline$\gamma$ & 2500 & & k & 0,059028 & \\
\hline Cenvironmental & 0,5 & & $\dagger$ & 75 & years \\
\hline Abh & 1,7 & $\%$ & y & 4,427083 & $\mathrm{~cm}$ \\
\hline & Cover & & 44,3 & & \\
\hline & $c+\Delta C$ & & 54,3 & $\mathrm{~mm}$ & \\
\hline
\end{tabular}

\section{INPUT DATA (gray)}

$$
\text { INPUT DATA (gray) }
$$

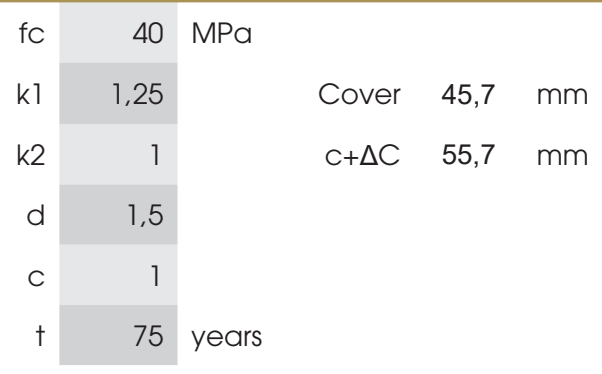

\begin{tabular}{|c|c|c|c|c|c|}
\hline \multicolumn{6}{|c|}{ INPUT DATA (gray) } \\
\hline & & & & \multicolumn{2}{|c|}{ Severe aggressiv } \\
\hline \multicolumn{6}{|c|}{ (a) } \\
\hline \multirow{6}{*}{$\begin{array}{r}\text { Cenvironmenta } \\
\text { Abh }\end{array}$} & 400 & $\mathrm{~kg} / \mathrm{m}^{3}$ & Clsup. & 0,0781 & $\%$ \\
\hline & 2500 & & k & 0,0781 & \\
\hline & 2,5 & & $t$ & 75 & years \\
\hline & 0,5 & $\%$ & y & 5,859 & $\mathrm{~cm}$ \\
\hline & Cover & & 58,6 & & \\
\hline & $c+\Delta C$ & & 68,6 & $\mathrm{~mm}$ & \\
\hline
\end{tabular}

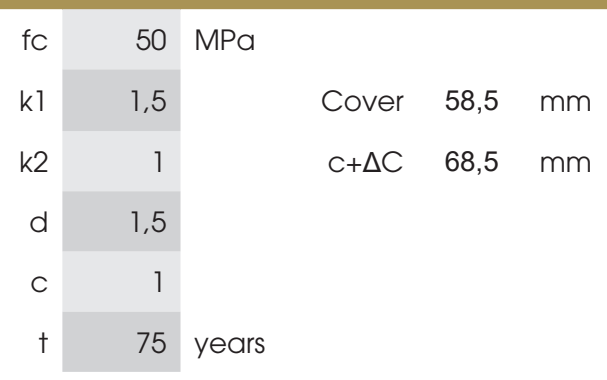

INPUT DATA (gray) 


\section{Table 14 - Recommendations for specification of concrete} to meet service life of 75 years for buried structures

\begin{tabular}{|c|c|c|c|c|c|c|}
\hline $\begin{array}{c}\text { Exposure } \\
\text { condition } \\
\text { due to the } \\
\text { aggressiveness }\end{array}$ & $\begin{array}{l}\text { Water-soluble } \\
\text { sulfate }(\mathrm{SO} 4) \text { in } \\
\text { the soil (wt\%) }\end{array}$ & $\begin{array}{l}\text { Concrete } \\
\text { class }\end{array}$ & $\begin{array}{l}\text { Maximum w/c } \\
\text { ratio a/c }\end{array}$ & $\begin{array}{c}\text { Minimum } \\
\text { cement } \\
\text { consumption } \\
\left(\mathrm{kg} / \mathrm{m}^{3}\right)\end{array}$ & $\begin{array}{l}\text { Type of } \\
\text { cement }\end{array}$ & $\begin{array}{c}\text { Nominal } \\
\text { covering } \\
\text { thickness }(\mathrm{mm})\end{array}$ \\
\hline Weak & 0,00 a 0,10 & C40 & 0,50 & 340 & $\begin{array}{l}\text { Cement } \\
\text { CPIIE or CPIIZ } \\
\text { or use } 5 \% \text { of } \\
\text { silica fume or } \\
\text { metakaolin }\end{array}$ & 45 \\
\hline Moderate & 0,10 a 0,20 & C40 & 0,40 & 370 & $\begin{array}{l}\text { Cement CPIII } \\
\text { (with at least } \\
60 \% \text { of slag) } \\
\text { or CPIV (with } \\
\text { at least } 30 \% \text { of } \\
\text { pozzolan) or } \\
\text { use of } 10 \% \text { of } \\
\text { silica fume or } \\
\text { metakaolin }\end{array}$ & 55 \\
\hline Severe & Above of 0,20 & C50 & 0,35 & 400 & $\begin{array}{c}\text { Resistant } \\
\text { cement sulfate }\end{array}$ & 70 \\
\hline
\end{tabular}

it is based on prescriptive rules of the Brazilian normative system; however, it provides no recommendation as to how to comply with the higher performance requirement. For instance, there is a gap on how to achieve superior performance for buried reinforced concrete structures, such as foundation blocks and stakes. In order to fill this gap, a review of the existing standards in the world and other relevant publications was carried out to support the decisionmaking. Confirmation through theoretical models for service life prediction was required to validate the comparison. It was concluded that to ensure a service life of 75 years, a buried concrete structure can be made of cement with additions, providing increased durability when in contact with contaminated areas or materials, thus preventing propagation of a potential alkali-aggregate reaction. Concrete dosage parameters were also determined in relation to compressive strength, water/cement ratio and cement consumption, in addition to nominal cover to steel bars, to ensure a service life of 75 years, superior level of the Performance standard.

\section{References}

[1] ASSOCIAÇÃO BRASILEIRA DE NORMAS TÉCNICAS. NBR 15575-2: Edificações habitacionais - Desempenho. Parte 2: Requisitos para os sistemas estruturais. Rio de Janeiro, 2013.

[2] ASSOCIAÇÃO BRASILEIRA DE NORMAS TÉCNICAS. NBR 6118: Projeto de estruturas de concreto - Procedimento. Rio de Janeiro, 2014.

[3] ASSOCIAÇÃO BRASILEIRA DE NORMAS TÉCNICAS. NBR 12655: Concreto - Controle, preparo e recebimento. Rio de Janeiro, 2015.

[4] ASSOCIAÇÃO BRASILEIRA DE NORMAS TÉCNICAS. NBR 8681: Ações e segurança nas estruturas - Procedimento. Rio de Janeiro, 2004.
[5] TUTIKIAN, B,F. ISAIA, G.C., HELENE, P. Dosagem dos concretos de cimento Portland In: ISAIA, Geraldo Cechella. Concreto: Ciência e Tecnologia. São Paulo: Ipsis. 2011. V.1. Cap. 12. P.415-452.

[6] BRITISH RESEARCH ESTABILISHMENT - BRE Construction Division. Concrete In Aggressive Ground (Special Digest 1). Garston, 2005.

[7] INDIAN STANDARD. IS-456: Plain and Reinforced concrete - Code of Practice. New Delhi, 2000.

[8] EUROPEAN STANDARD. EN 206-1: Concrete - Part 1: Specification, Performance, Production and Conformity. Brussels, 2000.

[9] AMERICAN CONCRETE INSTITUTE. ACI 318-11: Building Code Requirements for Structural Concrete and Commentary. Reported by ACl Committee, Detroit, Michigan, U.S.A., 2002.

[10] NEVILLE, A. M.; BROOKS, J.J. Tecnologia do Concreto. Bookman: São Paulo, 2013.

[11] BRITISH STANDARDS INSTITUTION. BS 8500-1: Concrete - Complementary British standard to BS EN 206-1 Part 1: Method of specifying and guidance for the specifier. London, 2006.

[12] CEMENT CONCRETE \& AGGREGATES AUSTRALIA CCAA. Chloride Resistance of Concrete. Sydney, 2009.

[13] FIGUEIREDO, Enio Pazini. Durabilidade e vida útil das estruturas de concreto. In: ISAIA, Geraldo Cechella. Concreto: Ciência e Tecnologia. São Paulo: Ipsis. 2011. V.1. Cap. 25. P.889-902.

[14] POLITO, Giuliano. Corrosão Em Estruturas De Concreto Armado: Causas, Mecanismos, Prevenção E Recuperação. 2006. 188 f. Trabalho de Conclusão de Curso (Graduação em Engenharia Civil) - Universidade Federal de Minas Gerais, Belo Horizonte, 2006. 
[15] AMERICAN SOCIETY OF CIVIL ENGGINEERS. ASCE 7-05: Minimum design loads for buildings and other structures. Virginia, 2005.

[16] MEHTA, P.K. E MONTEIRO, P.J.M. Concreto: Microestrutura, Propriedades e Materiais. 3. Ed. São Paulo: IBRACON, 2014.

[17] ISAIA, Geraldo Cechella. A água no Concreto. In: ISAIA, Geraldo Cechella. Concreto: Ciência e Tecnologia. São Paulo: Ipsis. 2011. V.1. Cap. 09.

[18] ASSOCIAÇÃO BRASILEIRA DE NORMAS TÉCNICAS. NBR 5736: Cimento Portland pozolânico. Rio de Janeiro, 1999.

[19] ASSOCIAÇÃO BRASILEIRA DE NORMAS TÉCNICAS. NBR 5735: Cimento Portland de alto-forno. Rio de Janeiro, 1991.

[20] ASSOCIAÇÃO BRASILEIRA DE NORMAS TÉCNICAS. NBR 15577: Agregados - Reatividade álcali-agregado. Parte 1: Guia para avaliação da reatividade potencial e medidas preventivas para uso de agregados em concreto. Rio de Janeiro, 2013.

[21] NAGESH, M. Notes on concrete durability chapter. Government Engineering College: Ramanagar, 2012.

[22] MEDEIROS, Marcelo Henrique Farias de; ANDRADE, Jairo José de Oliveira; HELENE, Paulo. Durabilidade e vida útil das estruturas de concreto. In: ISAIA, Geraldo Cechella. Concreto: Ciência e Tecnologia. São Paulo: Ipsis. 2011. V.1. Cap. 16. P.773-808.

[23] BOLINA, F. L.; TUTIKIAN, B. F. Parâmetros da estrutura de concreto armado Segundo os preceitos de desempenho, durabilidade e segurança contra incêndio. Concreto \& Construção, n.76, p.133-147, 2014.

[24] HELENE, P. Contribuição ao Estudo da Corrosão em Armaduras de Concreto Armado. Escola Politécnica da Universidade de São Paulo, São Paulo, 1993.

[25] BOB, C. Probabilistic Assessment of Reinforced Corrosion. In: Existing Structures. In: International Conference: Concrete Repair, Rehabilitation and Protection. Proceedings. Dundee, 1996.p.17-28.

[26] ASSOCIAÇÃO BRASILEIRA DE NORMAS TÉCNICAS. NBR 15577-1: Agregados - Reatividade álcali-agregado. Parte 2: Guia para avaliação da reatividade potencial e medidas preventivas para uso de agregados em concreto. Rio de Janeiro, 2008. 